DOI: 10.20472/AHC.2018.004.007

\author{
MICHAEL STRAWSER \\ University of Central Florida, United States
}

\title{
SPINOZA AND THE PHENOMENOLOGY OF JOY
}

\begin{abstract}
:
The focus of this presentation is twofold. First, I propose to examine the relationship between Spinoza and the phenomenological tradition, and then I shall attempt to offer a Spinoza-inspired phenomenological account of the experience of joy. On the first point, two recent works can be taken as suggesting that the relation between Spinoza's philosophy and phenomenology is an entirely antithetical one. In Spinoza Contra Phenomenology (2014), Knox Peden shows how the history of French rationalism from Cavaillès to Deleuze can be read as an attempt to utilize Spinoza in a defense against phenomenology. Then, in Out of Control: Confrontations between Spinoza and Levinas (2016), Richard Cohen presents a debate between the phenomenologist Emmanuel Levinas and the supposedly scientistic Spinoza, in which the two are viewed as complete antipodes. For Cohen, Levinas presents us with a radical phenomenologically grounded ethics, whereas Spinoza expresses a dehumanizing philosophy of science. With regards to Peden's work, I shall argue that while it may be fair to explain how certain "Spinozisms" are contrary to phenomenology, this does not establish the stronger claim that Spinoza's philosophy itself is antithetical to phenomenology. With regards to Cohen's work, I shall offer a corrective to the exaggerated and inadequate account of Spinoza as a hyper-rationalist by maintaining that a more complete account of Spinoza's view involving the embodied ethical emotions brings Levinas and Spinoza much closer together with regards to the primacy of ethics. After removing these problematic contrary views, I shall offer positive reasons for holding that Spinoza's philosophy may be fruitfully considered in relation to phenomenology. Here, the question is not "Was Spinoza a phenomenologist?" but rather "What would a Spinozist phenomenology look like?" and I shall suggest that Spinoza's emphasis on the role of intuition, as well as his understanding of embodied rationality and human affectivity, provide interesting possibilities. More specifically, I shall argue that Spinoza presents readers with a practical philosophy of life that is well attuned to lived human experience, such that the ultimate goal of human existence is joy or beatitude, which is not to be found in some otherworldly state, but rather can only be achieved as a lived experience through the activity of love.
\end{abstract}

\section{Keywords:}

Spinoza, phenomenology, joy, love, emotion, ethics 


\section{Introduction}

Joy, like love, is a well-worn word frequently used in manifold contexts to refer to multiple intentional objects and human experiences. What is joy? Are there different kinds of joy, and what is the relationship between love and joy? In this paper I shall attempt to answer these questions in at least a preliminary way, and in a way that is experimental for its attempt to consider both Spinoza's philosophy and the phenomenological method as providing a significant context for exploring these questions. The focus on Spinoza is relatively obvious, for joy is central to his philosophy. The focus of phenomenology is less obvious, but because the highest manifestation of joy for Spinoza involves a lived experience of virtue brought about through the practice of noble love, it makes sense to consider a method devoted to illuminating the essences of lived experiences. Consequently, the focus of this paper is twofold. First, I propose to examine, albeit briefly, the relationship between Spinoza and the phenomenological tradition, and then I shall attempt to offer a Spinoza-inspired phenomenological account of the experience of joy.

On the first point, the idea of considering possible connections between Spinoza and phenomenology is an unusual one, as there is very little scholarship on this, and two recent works suggest that the relationship between Spinoza's philosophy and phenomenology is an entirely antithetical one. In Spinoza Contra Phenomenology (2014), Knox Peden shows how the history of French rationalism from Cavaillès to Deleuze can be read as an attempt to utilize Spinoza in a defense against phenomenology. Then, in Out of Control: Confrontations between Spinoza and Levinas (2016), Richard Cohen presents a debate between the French phenomenologist Emmanuel Levinas and the supposedly scientistic Spinoza, in which the two philosophers are interpreted to be complete antipodes. For, as Levinas writes at the end of Section I in Totality and Infinity, "Thought and freedom some to us from separation and from the consideration of the Other-this thesis is at the antipodes of Spinozism." According to Cohen, Levinas presents us with a radical phenomenologically grounded ethics, whereas Spinoza expresses a dehumanizing rationalism and philosophy of science. What are we to make of these antithetical works, which at the very least suggest that a constructive appraisal of the relationship between Spinoza and phenomenology is an unlikely experiment?

With regards to Peden's work, I would argue that while it may be fair to explain how certain "Spinozisms" are contrary to phenomenology, this does not establish the stronger claim that Spinoza's philosophy itself is antithetical to phenomenology. In Spinoza Contra Phenomenology there is very little analysis of Spinoza's writings themselves, but instead a discussion of the so-called Spinozisms of thinkers such as Cavaillès, Althusser, and Deleuze, all of which suggest that this work could more appropriately be titled "Spinozisms contra phenomenology."

With regards to Cohen's work, I hope to offer a corrective to the exaggerated and inadequate account of Spinoza as a hyper-rationalist by maintaining that a more complete account of Spinoza's view involving embodied ethical emotions brings Levinas and Spinoza much closer together, for both thinkers embrace the primacy of ethics. Cohen writes that "Spinoza is obviously not a phenomenologist. His rationalism is radically opposed to any phenomenology,"2 but this view is offered as a fundamental pre-judgement, without any attempt to examine the phenomenological tradition (which obviously originates after Spinoza) and Spinoza's philosophy. But is it a forgone conclusion that rationalism and 
phenomenology are opposed? Could we not begin from another starting point-one that sees the Cartesian project to understand ideas clearly and distinctly as a prelude to the Husserlian enterprise? After all, Husserl's phenomenology famously involves Cartesian Meditations: An Introduction to Phenomenology in which he suggests that transcendental phenomenology might be called "a neo-Cartesianism," 3 and it is clearly the case that Spinoza's philosophy could not have been developed without a profound meditation on Cartesianism and its most challenging problems. Importantly, then, while Spinoza, Husserl, and later phenomenologists would all agree on the fecundity of Descartes' philosophy, they also agree on the rejection of Cartesian mind-body dualism and the significance of embodiment and lived experience.

Consequently, by removing these problematic contrary views we open the possibility for thinking that Spinoza's philosophy may be fruitfully considered in relation to phenomenology. Here, the question is not "Was Spinoza a phenomenologist?" but rather "What are the possible connections between Spinoza and phenomenology?" and "What would a Spinozist phenomenology look like?" To start with, I suggest that Spinoza's emphasis on the role of intuition, as well as his understanding of embodied rationality and human affectivity, provide interesting possibilities. More specifically, I shall argue that Spinoza presents readers with a practical philosophy of life that is well attuned to lived human experience, such that the ultimate goal of human existence is joy or beatitude, which is not to be found in some otherworldly, metaphysical state, but rather can only be achieved as a lived experience through the activity of noble love.

\section{Spinoza and Phenomenology Reconsidered}

While "French philosophers have always been particularly concerned to assess the precise nature of Spinoza's relationship to Descartes,"4 "Spinoza owes his position in the canon of Western philosophy to the historiography developed by German scholars in the Hegelian tradition." ${ }^{2}$ In consideration of this as well as the actual origins of the phenomenological tradition, it is important to consider the appraisal of Spinoza's thinking by prominent German phenomenologists and not limit our reflections to comparisons with French thinkers and the French phenomenological tradition.

In the $19^{\text {th }}$ century, Spinozism was seen "first and foremost as an alternative to German idealism," 6 and in the influential study Spinoza: His Life and Philosophy (1880), Sir Frederick Pollock writes: "Spinozism, as a living and constructive force, is not a system, but a habit of mind."7 This is an important perspective from which to consider the project of thinking about Spinoza and phenomenology. For Edmund Husserl, the originator of contemporary phenomenology, his philosophy was always viewed as a descriptive methodology and never a system. And according to Max Scheler, one of the most popular early collaborators with Husserl, phenomenology should best be understood as "a way of seeing." While it may be the case that Spinoza attempts to construct a rational system, this is a project that is certainly inherited from Descartes, it is arguable-as suggested by Pollock's view-that what is most important for Spinoza is the cultivation of a way of seeing that informs practical living.

There are additional points of contact between Husserl's phenomenology and Spinoza's philosophy. In one regard, there appears to be a deep congruence in the manner in which Husserl proposes to develop his Logical Investigations and the manner in which Spinoza develops his ideas geometrically in Ethics. The central aim of Husserl's investigations if to 
provide a clarification of pure logic by moving beyond "remote, confused, inauthentic intuitions - if by any intuitions at all-[to] ...go back to the 'things themselves' [Zu den sachen selbst!." 8 The so-called "things" Husserl is after are "completely self-evident truths of essence," 9 and Spinoza's geometrical proofs are also intended to provide us with fully adequate ideas the reveal the essences of the key concepts of metaphysics, epistemology, ethics, and the emotions, "for the eyes of the mind, by which it sees and observes things, are demonstrations." 10 Further, as Spinoza writes, "it is the nature of reason to perceive things under a certain species of eternity," 11 and this perspective aligns with Husserl's goal to arrive at essential structures through an eidetic reduction. For Husserl, the evidence of his ideas is given through intuition, which is perhaps best though about mathematically as a form of mental seeing, and for Spinoza, the highest form of knowledge is intuition, and it is significant that it is this form of knowledge alone that yields certain ethical truths required for the achievement of joy. So, while for Husserl the main goal of phenomenology is an intuitive grasping of "the things themselves," such is also the goal for Spinoza, who argues that the free person is one of fortitude who "endeavours above all to conceive things as they are in themselves." 12

Despite these key points of shared perspective, there are no references to Spinoza in Husserl's breakthrough Logical Investigations, and one key difference between the thinking of Husserl and Spinoza is that Husserl largely gets stuck in the attempt to ground his epistemological analyses and consequently completely lacks any ethical system. Whereas Spinoza, who could not be said to subscribe to Husserl's "principle of all principles"-the freedom of presuppositions-makes certain metaphysical presuppositions in order to deduce what is of most importance to him, and as signified by the title of his greatest work, this is Ethics. In other words, Husserl is most concerned with the understanding the possibility of understanding itself in an effort to ground all knowledge, whereas for Spinoza the project of understanding is only a prerequisite intended to serve the highest goal of his philosophy, which is the ethical goal, namely "to act well and rejoice." 13

Thus, it is reasonable to bring Levinas and Spinoza into dialogue, for both emphasize the primacy of ethics, although Cohen surprisingly fails to recognize this point is his work. Instead, Cohen repeatedly attempts to reinforce the claim that Levinas's "thesis is at the antipodes of Spinozism," but even if we accept this as the case, in this passage Levinas is making a metaphysical claim along with an interpretation of Spinoza's metaphysical claim, both of which are ultimately undecidable. So, the question would then be this: whose philosophy is more practical, transformative, and empowering? This question brings our philosophers closer together, but the upper hand must go to Spinoza, who provides an ethical way of living leading to joy, whereas Levinas offers profound, but abstract reflections on a responsibility to the other that can never be fulfilled.

Alternatively, one way that we can interpret Levinas's thesis so that is not antipodal to Spinoza's philosophy is by taking Spinoza's doctrine of modes seriously. While this doctrine suggests that as modes we are indeed separate, it calls for us to transcend our modal nature (a kind of transcendence in Spinoza!) by considering the Other (i.e., God) who is manifest immanently as Nature (Deus sive Natura) and most clearly embraced through relations with other human beings. Only in relation to the Other and to others (i.e., understanding ourselves as interconnected to the whole and overcoming the modal separation) is it possible to be free. ${ }^{14}$ 
In German phenomenology, the thinker who most embraces the primacy of ethics is Max Scheler. While Scheler praises Husserl for his new way of spiritual seeing with its focus on "genuine intuitive essences," 15 he also finds problematic the absence of an ethics in Husserl's thought and his neglect of the person and avoidance of explaining emotion and its significance. For Scheler, "phenomenological philosophy is one which undertakes to look on the essential fundamentals of all existence with rinsed eyes,"16 and "the main objective" of his greatest work, Formalism in Ethics and Non-Formal Ethics of Values, "is to establish a strictly scientific and positive foundation for philosophical ethics with respect to all its fundamental problems." 17 Given this focus on ethics in Scheler's work, it is perhaps not surprising that he refers to Spinoza as an authority in the first paragraph of his Formalism, writing that "in the final analysis Spinoza's dictum, 'Truth is the criterion of itself and the false,' obtains in philosophy." 18 Thus, it would also be valuable to bring Scheler and Spinoza into dialogue in a reconsideration of Spinoza and phenomenology, but given limited space and time such a dialogue, even in a preliminary fashion, cannot be accomplished here. Suffice it to say that Scheler respected Spinoza's thinking and appreciated his understanding of joy, as seen in the following quotation, which may serve as both a transition and goal:

The extent to which Spinoza knew this joy in ability as such [i.e., being able to do what one ought to do] becomes apparent in his famous saying, "Blissfulness [Beatitudo] is no reward of virtue; it is virtue itself." For no doubt this blissfulness means this particular joy as conjoined with the highest consciousness of power and freedom. ${ }^{19}$

\section{Towards a Spinozist Phenomenology of Joy}

Let us note from the outset that for Spinoza the highest expression of joy-which is to say beatitudo, variously translated as "blissfulness" or "blessedness"-is an experience derived from love and thus requires love as its precondition. Obviously, by writing "the highest expression of joy" I am already signaling that there is another expression of joy in Spinoza's Ethics, and complicates out attempt at a clear understanding. We also find that love, which is an even more worn out word than joy, is used in different ways by Spinoza, or at least in ways implying that some usage of the word is improper, or common or vulgar, which is what Pausanias suggests in distinguishing "common Aphrodite" from "heavenly Aphrodite" in his speech in Plato's Symposium. ${ }^{20}$ Thus, we should not be surprised to find that "joy" is commonly used in an ambiguous manner, and we may need to distinguish common joy from genuine or true joy.

As already suggested, the fact that Spinoza entitled his greatest work "Ethics" is decisive, for it highlights what is most central in Spinoza's vision, and this is not metaphysics or epistemology as commonly interpreted, but rather a practical ethics of life. Had Spinoza wished to highlight something else, he could have entitled his greatest work "Truth," "Knowledge," or "The Way of Reason," but he did not. Nor did he call it "God" or "Nature," which would not have been unreasonable. Instead, his work is simply titled Ethics, signifying that the heart and key value of this work lies in communicating the proper way of living or acting in the world. Not surprisingly, then, a vision of love can be found pulsating through this heart, and one that leads to beatitudo or blessedness, which is for Spinoza the highest experience of joy.

We all know that coming to terms with love is difficult, and as mentioned above, there is some ambiguity in Spinoza's presentation of love in his Ethics. Spinoza first writes of 
love as a passion, defined as "joy/pleasure accompanied by the idea of an external cause." 21 Lætitia is the original word that has been translated variously as both "joy" and "pleasure," thus establishing a clear link between love and joy, although joy must be understood here as equivalent to the common sense of pleasure, which for Spinoza is one of three basic emotions and is defined as follows:

the passion by which the mind passes to a greater perfection.... Further, I call the emotion of pleasure, in so far as it is related simultaneously to the mind and the body, either 'titillation' or 'joy'."22

The fact that both love and joy are understood as passions does not imply for Spinoza that they are to be avoided, although the free, wise person will strive to be as active as possible in order to come as close as one can in life to the experience of perfect joy or blissfulness.

In order for this to happen, we need an active expression of love, and there is another term Spinoza uses to refer to what we may understand as active love, and that is "nobility" (generositas). Not surprisingly, this term is repeatedly equated with love. ${ }^{23}$ After fifty-seven propositions in Part Three that explain "the origin and nature of the emotions" and categorize forty-six passive emotions, ${ }^{24}$ Spinoza writes only two propositions which explain active emotions rather than passions. In the scholium to the last of these, Spinoza writes that all active emotions are related to fortitude, which covers two categories of emotions, courage and nobility, the latter of which he understands, as "the desire by which each person, in accordance with the dictate of reason alone, endeavors to help [others] and join them [...] in friendship." 25 Thus, for Spinoza active love is rational and ethically qualified, which is to say it is essentially directed towards another person, as a free, active person will try to help others, and aid in their transition from lesser to greater perfection, and this makes up a central feature of a way of living that leads to the experience of blessedness.

The free and wise person will attempt to "bring it about that we are not easily affected by bad emotions," 26 for all bad emotions involve pain, but the passive emotions that involve pleasure will be so ordered that the active, rational emotions are meditated on so as to be always close at hand. Spinoza explains: "The best we can do, therefore, as long as we do not have perfect knowledge of our emotions, is to conceive a right way of living, i.e. fixed rules of life, that are certain, and to commit these to memory and apply them constantly to particular things that meet us in life...."27 Of these fixed rules, Spinoza mentions surprisingly but one: "love, i.e. nobility." For Spinoza we have no absolute rule over the passions, but significantly two individuals in union are more powerful than one. ${ }^{28}$ Consequently, uniting with other free persons through love is the precondition and cause of joy, and in such a union the essential equality of humanity is a requirement for this joy to be experienced. Granted, one may experience pleasure while in an asymmetrical, unequal relationship in which one partner possesses power over the other, but such a relationship will not leads to a full experience of joy. Even in the case of the parent-child relationship, which may be the source of some of the richest experiences of joy (since the perception of the transition from lesser perfection to a greater one is most readily given), this is only possible when there is the recognition of the equal rights of the child as an free human being. Thus, there is an essential ethical component to both love and joy. 
Spinoza's philosophy of love implies that joy can be understood as both a passive and active phenomenon, insofar as we understand blissfulness (beatitudo) as the greatest expression of joy brought about through the practice of active love or nobility. In his recent work Coming (La Jouissance), the contemporary French philosopher Jean-Luc Nancy admires Spinoza's view of joy, and in the "Preface to the English-Language Edition" of La Jouissance, Nancy explains how this French word ambiguously conveys both possession and sexual pleasure, with the latter designation expressing an action or movement that "remains irreducible either to a state or to an acquisition, to an accomplishment or to an appropriation." 29 To account for this duality, translator Charlotte Mandell chooses the gerund "coming" to highlight this irreducibility and thereby directly links the conception of joy to sexual orgasm. Nevertheless, the etymology of jouissance, as Nancy explains, "goes beyond the realm of sexuality" 30 and "evokes two terms that belong to the same lexical field: on one hand, joy [joie]; on the other, rejoicing [réjouissance]. ${ }^{31} \mathrm{Joy}$, then, is possible without jouissance; it is seen as "spiritual," that which elevates us, whereas jouissance is more physical.

Pleasure and joy can thus be distinguished, as the former involves a subjective feeling that is for myself alone, while "joy carries me rather outside of myself, towards something else." 32 Given this explanation, it is easy to understand why joy and love are closely related experiences, as the conception of love that can be derived from Plato also lifts us to something outside of ourselves, and ultimately, as Diotima instructs Socrates, when developed properly this can lead to "bliss and shared understanding."33 Another word used to express this experience is "beatitude," a word Nancy associates with Spinoza:

If I think of this word, it's because we find it in Spinoza, for whom joy occupies a very important place, starting from the basic difference between joyful passions and sad passions. Yet beatitude, in Spinoza, is first of all the state we reach when we are in the love of God, which for Spinoza is synonymous with intellectual love. Today, this term has become outmoded, almost ridiculous, but Spinoza defines it in the final proposition in his Ethics in a way I find truly admirable: "Beatitude is not the reward of virtue, but its very practice." Here we should not understand virtue in the moral sense, like total compliance with a certain moral demand. Virtus in Latin is the exercise of a force that is positive, the force of striving toward that love of God who is at the same time (since God, for Spinoza, is nature) the love of nature, the love of the world, of Being in general. With Spinoza, one can say that whereas pleasure is above all centripetal and appropriative, joy, on the other hand, centrifugal and dis-appropriative, a disposition that is both active and striving towards something outside. ${ }^{34}$

From this account of Spinoza we get the impression that joy and beatitude are intertwined, for in Nancy's initial distinction between pleasure and joy it is the latter that "carries me rather outside myself, towards something else," 35 and the above passage seems to suggest (with the exception of one point to which we shall soon return) that the joyful passions or emotions are part of the active practice of virtue that leads "towards something outside." 36 While this reading is suggestive and seemingly points towards transcendence, those familiar with Spinoza will no doubt wonder how the great philosopher of immanence can be read as "striving towards something outside." On the one hand, Spinoza's understanding of substance shows that there is absolutely nothing 
outside of God or nature. On the other hand, as suggested above in reflections on Levinas's opposition to Spinoza, it is clear that from a modal perspective one can strive to transcend oneself by embracing the Other. The striving, then, from a God's eye view occurs necessarily within immanence, but from a limited perspective of human existence there is transcendence brought about through the proper striving to increase my force or power. This occurs through practicing virtue and the attendant active emotions, and I (if we can still use this word) thereby experience the height of joy which is beatitude. Can this experience thus be understood as a "state," which implies a static conception that conflicts with the interpretation of movement and striving with an emphasis on an experiential practice? Nancy's reading exposes this ambiguity, as seen in the understanding of beatitude as "the state we reach when we are in the love of God," ${ }^{37}$ and he goes on to distinguish joy or jouissance as "a movement, and impulse [élan] and a passage, whereas beatitude (also called "felicity") designates a state, the state of knowledge of God or of the whole order of nature." 38 But doesn't this contradict the view that beatitude is a practice? Although he doesn't respond to this directly, Nancy attributes the ambiguity to "the difference between tension and accomplishment, or between movement and rest." 39 While we can see how this reading would fit with a mystical interpretation of the culmination of Spinoza's thinking, can we understand the conatus in a state of rest? Wouldn't this be a contradiction in terms? Nancy seems aware of this insofar as he nevertheless continues to understand virtue as an "active power [and] also a desire, or an appetite: not desire for an object but the desire of 'persevering in one's being,' that is, going as far as possible in the act of existing." $40 \mathrm{He}$ continues:

So beatitude is a state in which the desiring act is constantly renewed, re-launched. Spinoza notes that "we experience joy from it" by using the verb gaudere (from which "joy" and jouissance derive) and not laetare (whereas he first called joy laetitia, a more spiritual joy, less agitated or tumultuous. ${ }^{41}$

This "state" can thus not be understood passively, in the fleeting sense of rest, or at least this would not be what produces the joy we experience, but rather in the continuous desire that is ever renewed, which suggests more the joy of becoming than of being, of transitioning to more active, powerful, and perfect being. Although it is not mentioned in Nancy's text, it is worth noting that since God is perfection, there can be no transitioning and consequently no joy in achieving the renewal of desire, which seems more indicative of how we commonly understand the notion of a "state." Be this as it may, Nancy does make the interesting comment that although "Spinoza is far from praising sexual jouissance, ... his thinking about the desire to be in an infinitely renewed impulse [élan] of correspondence with the infinite itself, with all the excess that one might find in it, has something remarkably sexual about it, although Spinoza himself does not note this." 42 This fits nicely within the context of jouissance as "coming," and the idea of relaunching one's sexual desire after an orgasm has been achieved is clear enough, but if we reflect on this experience further it seems that the greatest experience of joy, what we would perhaps want to call beatitude, does not lie in the rest that comes after coming, for as Jean-Luc Marion explains in The Erotic Phenomenon, "orgasm is not a summit, from which one would descend in stages; it resembles a cliff that opens onto a void, where one falls all at once." 43 Marion's phenomenology of love offers 
significant points for consideration, as his description of the erotic experience is univocal phenomenon that transcends the sexual and thus cannot be reduced to mere sex alone. Additionally, Marion also makes an important distinction between pleasure and joy, where the former involves "my reception by the other's flesh, such that it gives me my own flesh," 44 while the latter involves the glorious face of the other and the crossing of flesh such that I experience the other enjoying her flesh. He writes:

Thus I enjoy her. Put another way, I do not enjoy my pleasure, but hers; and if, by chance (which does not go without saying), I also climax, this pleasure gushes forth only from hers, as its undertow; if I climaxed without her climax, I would simply not enjoy, but instead would limit myself to using her anew. Of themselves, a discharge and a spasm do not allow enjoyment, even if by chance they accompany my pleasure. Infinitely more than pleasure, even multiplied and violent, is necessary for enjoyment. The crossing of flesh is necessary. ${ }^{45}$

Thus, we return to the idea that I have tried to underscore in this essay, namely, that joy is our experience of the positive growth or transformation or transition to greater perfection of the other person whom we love. In this regard it is a doubly positive emotion as our own feeling of power is increased in our perception of an other's experience of increased power. ${ }^{46}$

The contemporary French philosophers Nancy and Marion add to this study of Spinoza and the phenomenology of joy in important ways, but both also suggest a problem. As quoted above, Marion writes that "infinitely more than pleasure, even multiplied and violent, is necessary for enjoyment." 47 What does this reference to violence mean? Further, we have already seen Nancy's admiration for Spinoza, yet surprisingly this does not prevent him from accepting with Marquis de Sade that joy (jouissance) can "be born from pain inflicted on another or on oneself." ${ }^{8}$ Spinoza, however, provides a necessary corrective to this inadequate view.

Is it possible to feel joy over another's pain? In this paper, I have suggested that love is best understood as an essentially ethical activity, and that joy is a phenomenon that is derived from this. Thus, I would maintain that there may be love without joy, for joy involves a recognition of the other's experience through which I find myself in the other, but there cannot be joy without love. Further, a distinction between pleasure and joy, or Spinoza's laetitia and beatitudo, allow us to suggest that while it is possible to experience pleasure over another's pain, which we all naturally do when we hate the other in question, joy is a more excellent and rare phenomenon in which we experience the other's growth or transition from a less perfect manner of acting to a more perfect manner of acting, or, in other words, we experience the other's becoming perfect.

\footnotetext{
${ }^{1}$ Emmanuel Levinas, Totality and Infinity, translated by Alphonso Lingis (Pittsburgh, PA: Duquesne University Press, 1961), 105.

${ }^{2}$ Richard A. Cohen, Out of Control: Confrontations between Spinoza and Levinas (SUNY Press, 2016), 292.
} 
${ }^{3}$ Edmund Husserl, Cartesian Meditations: An Introduction to Phenomenology, translated by Dorion Cairns (The Hague: Martinus Nijhoff Publishers, 1960), 1.

${ }^{4}$ Wiep van Bunge, et al., eds., The Bloomsbury Companion to Spinoza (London: Bloomsbury, 2014), 365.

${ }^{5}$ Bunge, The Bloomsbury Companion to Spinoza, 362.

${ }^{6}$ Bunge, The Bloomsbury Companion to Spinoza, 364.

${ }^{7}$ Bunge, The Bloomsbury Companion to Spinoza, 364.

${ }^{8}$ Edmund Husserl, Logical Investigations, translated by J. N. Findlay (London: Routledge \& Kegan Paul, 1970), 252.

${ }^{9}$ Husserl, Logical Investigations, 254.

${ }^{10}$ Baruch Spinoza, Ethics, edited and translated by G. H. R. Parkinson (Oxford University Press, 2000). Throughout this paper I shall follow the standard style for citing Spinoza's Ethics, where 'E' stands for the part of Ethics, 'p' for proposition, 's' for scholium, and 'c' for corollary. Thus, the reference for this passage is E5p23s

${ }^{11}$ Spinoza, E2p44c2.

${ }^{12}$ Spinoza, E4p73s.

${ }^{13}$ Spinoza, E4p73s.

${ }^{14}$ Here I would pose a question for Levinas: If God is pure freedom and if we are radically separated from him, then how is it possible for us to become free?

${ }^{15}$ Max Scheler, Formalism in Ethics and Non-Formal Ethics of Values, in The Phenomenology Reader, edited by Dermot Moran and Timothy Mooney (London: Routledge, 2002), 203.

${ }^{16}$ Scheler, Formalism, in The Phenomenology Reader, 199.

${ }^{17}$ Max Scheler, Formalism in Ethics and Non-Formal Ethics of Values, translated by Manfred S. Frings and Roger L. Funk (Evanston, IL: Northwestern University Press, 1973), xvii.

${ }^{18}$ Scheler, Formalism, 5.

${ }^{19}$ Scheler, Formalism, 235.

${ }^{20}$ Plato, Symposium, in Plato on Love, edited by C. D. C. Reeve (Indianapolis: Hackett, 2006), pp. 36-37.

${ }^{21}$ Spinoza, E3p13s.

${ }^{22}$ Spinoza, E3p11s.

${ }^{23}$ The evidence that grounds our interpretation of nobility as love is found in the text itself. Significantly, in proposition 46 in Part Four Spinoza writes: "Someone who lives in accordance with the guidance of 
reason endeavors, as far as he can, to repay the hatred, anger, contempt, etc. that another has for him with love, i.e. with nobility" (E4p46). So, now, for Spinoza, it is clear that by "love" he means nobility, amor sive generositas (and in the demonstration of this proposition Spinoza refers readers to the initial reference to nobility as well as the proposition that hatred can be extinguished by love [E3p43]). This means we are no longer to think of love as a passion "accompanied by an external cause," but rather as a purely internal movement of the self. Following the command of reason, it is clear that one shall love, and through acts of love one strengthens and preserves one's own being. Without love one lives miserably (E4p46s).

In the final scholium in Part Four we read:

These and similar things that I have demonstrated about the true freedom of man are related to fortitude, that is to courage and nobility. I do not think it worthwhile to demonstrate here, one by one, that a free man hates no one, is angry with no one, envies no one, is indignant with no one, despises no one, and is far from being proud. For these, and all the things that relate to true life and religion, are easily demonstrated from Props. 37 and 46 of this Part: namely, that hatred is to be conquered by love, and that each person who is led by reason desires that the good that he seeks for himself should also exist for others. (E4p73s)

There are other passages in the Ethics where Spinoza indicates the equivalence of love and nobility, but we do not need to continue our exposition of this point. We are now justified in reading Spinoza's Ethics as centered on the philosophy of love, in which love is conceived most distinctly as an active internal movement whereby one acts to strengthen the other.

${ }^{24}$ Of the forty-eight emotions listed in the "Definitions of the Emotions," at the end of Part Three, only the first two listed, desire and pleasure, can also be considered as actions. This is clear from proposition 58: "Besides the pleasure and the desire which are passions, there exist other emotions of pleasure and desire which are related to us in so far as we act."

${ }^{25}$ Spinoza, E3p59s.

${ }^{26}$ Spinoza, E5p10s.

${ }^{27}$ Spinoza, E5p10s.

${ }^{28}$ Spinoza, E4p18s.

${ }^{29}$ Jean-Luc Nancy with Adèle van Reeth, Coming, translated by Chalotte Mandell (New York: Fordham University Press, 2017), p. viii.

${ }^{30}$ Nancy, Coming, p. 3.

${ }^{31}$ Nancy, Coming, p. 4.

${ }^{32}$ Nancy, Coming, p. 5.

${ }^{33}$ Plato, Phaedrus, in Plato on Love, edited by C. D. C. Reeve (Indianapolis: Hackett, 2006), 121 (256b).

${ }^{34}$ Nancy, Coming, p. 6. 
${ }^{35}$ Nancy, Coming, p. 5.

${ }^{36}$ Nancy, Coming, p. 6.

${ }^{37}$ Nancy, Coming, p. 6.

${ }^{38}$ Nancy, Coming, pp. 6-7.

${ }^{39}$ Nancy, Coming, p. 7.

${ }^{40}$ Nancy, Coming, p. 7.

${ }^{41}$ Nancy, Coming, p. 7.

${ }^{42}$ Nancy, Coming, p. 7.

${ }^{43}$ Jean-Luc Marion, The Erotic Phenomenon, translated by Stephen E. Lewis (Chicago: The University of Chicago Press, 2007), 135.

${ }^{44}$ Marion, The Erotic Phenomenon, p. 119.

${ }^{45}$ Marion, The Erotic Phenomenon, p. 128.

${ }^{46}$ The experience that we have when we experience our own transformation towards perfection is selfcontentment, which is not as strong as the experience of joy.

${ }^{47}$ Marion, The Erotic Phenomenon, p. 128.

${ }^{48}$ Nancy, Coming, p. 56. Strictly, it is Nancy's interlocutor Adèle van Reeth who makes this point, but Nancy says nothing to call it into question. 